
ЫНТАЛАНДЫРУШЫ ФАКТОРЫ РЕТІНДЕ

\title{
INVESTMENTS AS A STIMULATING FACTOR IN THE AIC DEVELOPMENT IN KAZAKHSTAN
}

\section{ИНВЕСТИЦИИ КАК СТИМУЛИРУЮЩИЙ ФАКТОР РАЗВИТИЯ АПК КАЗАХСТАНА}

\author{
Ш.А. СМАҒҰЛОВА* \\ э.F.Ә., профрессор \\ Нархоз университеті, Алматы, Қазақстан \\ *автордың электрондық поштасы: shsmagulova@mail.ru \\ SH.A. SMAGULOVA* \\ Dr.E.Sc., Professor \\ Narxoz University, Almaty, Kazakhstan \\ *corresponding author e-mail: shsmagulova@mail.ru \\ Ш.А. СМАГУЛОВА * \\ Ә.э.н., профрессор \\ Университет Нархоз, Алматы, Казахстан \\ *электронная почта автора:shsmagulova@mail.ru
}

\begin{abstract}
Аңдатпа. Мақсаты - Қазақстанның агроөнеркәсіптік кешеніндегі қызметті тиімді басқару және ынталандыру үшін инвестициялық жобалаудың ұйымдастырушылық-экономикалық аспектілерін зерттеу. Әдістері - библиометрикалық, топтастыру және жалпылау, бақылау, синтез және салыстырмалы талдау. Нәтижелері - инвестициялық менеджмент жобаларын оңтайландыру бойынша алғашқы дереккөздерге шолу жасалған. Covid-19 пандемиясы жағдайында елдегі әлеуметтік-экономикалық жағдайға баға берілген. Ауыл шаруашылығы өнімдерінің (өсімдік шаруашылығы және мал шаруашылығы салаларының) өсуі байқалады. Соңғы тоғыз жылда "негізгі капиталға инвестициялар" құрылымында аграрлық секторға инвестициялардың үлесі айқындалды. Субсидиялау, жеңілдікті салық салу, кедендік баждарды ұсыну негізінде жобалық қаржыландыру саласында ауыл шаруашылығы тауарын өндірушілерді мемлекеттік қолдаудың нысандары мен шаралары жинақталған. Республиканың өңірлері бойынша инвестициялық жобалардың іске асырылуы көрсетілген. Инвестицияларды бөлуге және өңдеу зауыттарын, фермаларды, жылыжайларды құруда жаңа ақпараттық технологияларды, цифрлық жүйелерді енгізу қажеттігіне баса назар аударылған. Техника мен жабдықтың негізгі түрлерінің жай-күйіне талдау жасалған, олардың тозуының жоғары дәрежесі көрсетілген. Қортындылар - инвестициялық дизайн қажетті инвестициялардың мөлшерін бағалауға, экономикалық орындылықты есептеуге және ықтимал қауіптерді ескеруге мүмкіндік береді. Ақша салуға байланысты бизнес-жобаларды бағалау олардың жіктелуіне негізделуі керек. Инвестициялау мақсаттары бойынша: шығарылатын өнімдердің көлемін ұлғайтуды, олардың ассортиментін кеңейтуді, өнімдер мен қызметтердің сапасын арттыруды, ауыл шаруашылығы кәсіпорнының шаруашылық қызметін жаңартуды, тауарлар мен сервистің өзіндік құнын төмендетуді қамтамасыз етеді. Тәуекелдерді азайту үшін шаруашылық жүргізуші субъектінің менеджменті қолайсыз жағдайларды болжауға және алдын-алу шараларын қабылдауға бағытталуы керек. Инвестициялық бағдарламаларды орындау бойынша ұсыныстар мен ұсынымдар әзірленген (мемлекеттік қаржыландыру мөлшерінің өсуі, ауыл шаруашылығы тауарын өндірушілер үшін кредиттік ресурстардың қолжетімділігін арттыру, жаңа технологияларды енгізу).
\end{abstract}

Abstract. The goal is to study the organizational and economic aspects of investment design for effective management and stimulation of activities in agro-industrial complex of Kazakhstan. Methods - bibliometric, grouping and generalization, observation, synthesis and comparative analysis. Results - a review of primary sources on optimization of investment management projects was carried out. An assessment of the socio-economic situation in the country in the context of the COVID19 pandemic is presented. There is an increase in agricultural production (crop and livestock sec- 


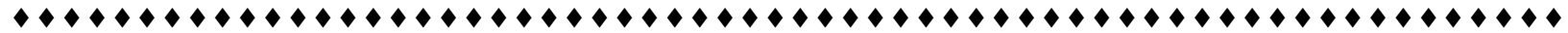
tors). The share of investments in agricultural sector in the structure of "Investments in fixed assets" for the last 9 years has been determined. Forms and measures of public support for agricultural producers in the field of project financing based on subsidies, preferential taxation, and provision of customs duties are generalized. The implementation of investment projects in the regions of the republic is shown. Emphasis is placed on distribution of investments and the need to introduce new information technologies, digital systems in the creation of processing plants, farms, greenhouses. The state of the main types of machinery and equipment is analyzed, and a high degree of wear is indicated. Conclusions - investment design allows to estimate the size of the required investments, calculate the economic feasibility and take into account possible threats. The assessment of business projects related to the investment of funds should be based on their classification. For investment purposes: ensuring an increase in the products volume, expanding their range, improving the quality of products and services, updating economic activities of agricultural enterprise, reducing cost of goods and services. To minimize risks, the management of an economic entity should be focused on anticipating unfavorable situations and taking preventive measures. Proposals and recommendations on the implementation of investment programs (an increase in the size of government funding, an increase in the availability of lending resources for agricultural producers, introduction of new technologies) were developed.

Аннотация. Цель - исследовать организационно-экономические аспекты инвестиционного проектирования для эффективного управления и стимулирования деятельности в агропромышленном комплексе Казахстана. Методы - библиометрический, группировки и обобщения, наблюдения, синтеза и сравнительного анализа. Результаты - выполнен обзор первоисточников по оптимизации проектов инвестиционного менеджмента. Дана оценка социально-экономической ситуации в стране в условиях пандемии COVID-19. Отмечается рост продукции сельского хозяйства (отраслей растениеводства и животноводства). Определена доля инвестиций в аграрный сектор в структуре «Инвестиции в основной капитал» за последние 9 лет. Обобщены формы и меры государственной поддержки сельхозтоваропроизводителей в сфере проектного финансирования на основе субсидирования, льготного налогообложения, предоставления таможенных пошлин. Показана реализация инвестиционных проектов по регионам республики. Сделан акцент на распределение инвестиций и необходимость внедрения новых информационных технологий, цифровых систем в создание перерабатывающих заводов, ферм, теплиц. Проанализировано состояние основных видов техники и оборудования, указывается высокая степень их износа. Выводы - инвестиционное проектирование позволяет оценить размер необходимых вложений, рассчитать экономическую целесообразность и учесть возможные угрозы. Оценку бизнес-проектов, связанных с вложением денежных средств, следует основывать на их классификации. По целям инвестирования: обеспечивающие увеличение объемов выпускаемых продуктов, расширение их ассортимента, повышение качества продукции и услуг, обновление хозяйственной деятельности сельхозпредприятия, снижение себестоимости товаров и сервиса. Для минимизации рисков менеджмент хозяйствующего субъекта должен быть нацелен на предвидение неблагоприятных ситуаций и принятие предупреждающих мер. Разработаны предложения и рекомендации по выполнению инвестиционных программ (рост размеров государственного фринансирования, увеличение доступности кредитных ресурсов для сельскохозяйственных товаропроизводителей, внедрение новейших технологий).

Түйінді сөздер: агроөнеркәсіптік кешен, ауыл шаруашылығы тауарын өндірушілер, өсімдік шаруашылығы, мал шаруашылығы, өндіріс, қайта өңдеу, инвестициялық жобалау, кредиттік ресурстар, жеңілдікті салық салу, инновациялық технологиялар.

Key words: agro-industrial complex, agricultural producers, crop production, livestock production, production, processing, investment design, lending resources, preferential taxation, innovative technologies.

Ключевые слова: агропромышленный комплекс, сельхозтоваропро-изводители, растениеводство, животноводство, производство, переработка, инвестиционное проектирование, кредитные ресурсы, льготное налогообложение, инновационные технологии.

Kiрicne. COVID-19 негізіндегі эпидемиологиялық күйзелістер жаһандық дағдарысқа әкелді. Бұл біздің елдің ғана емес, бүкіл әлемнің азық-түлік қауіпсіздігіне тікелей әсер етті.
Қолайсыз климаттық жағдайлар, қаржылық тәуекелдер, белгілі бір аймақтарда су ресурстарының жетіспеушілігі, техниканың жоғары тозуы ауыл шаруашылығы үшін күрделі проблемаға айналды. Осыған 
байланысты бағаның өсуі, сонымен қатар әлемде ауыл шаруашылығы өнімдеріне сұраныстың артуы байқалады. Назар аударыңыз, 2020 жылы ішкі жалпы өнімнің жалпы деңгейі төмендеді және теріс мәнге ие болды - 2,6\% [1].

Қазіргі уақытта 2021 жылдың соңына қарай Қазақстанның ұлттық экономикасы біртіндеп қалпына келе бастады. Бұл, ең алдымен, мұнай бағасының өсуіне және энергияға әлемдік сұраныстың әсерінен. Сонымен, 2020 жылдың екінші жартысында экономикалық өсім басталды. Рас, нақты ЖІӨ деңгейі 2019 жылдың нәтижесінен, яғни COVID дағдарысы пандемиясына дейін әлі де төмен екенін атап өткен жөн.

Атап айтқанда, 2020 жылы ауыл шаруашылығы өнімдерінің көлемі 6 триллионнан теңге астам соманы құрады (ЖІӨ-ге 5,6 пайызға өсім). Құрылымы бойынша ауыл шаруашылығы өнімдерінің бұл өсуі өсімдік шаруашылығының (7,8\%) және мал шаруашылығының (3\%) өсуімен байланысты. Болжам бойынша, 2021 жылы ауыл шаруашылығының үлесі ЖІӨ-нің 5 пайызынан асады [2].

Бүгінде аграрлық сектор Үкіметтің негізгі басымдықтарының бірі болып табылады. Мұнда еңбекке жарамды халықтың миллионнан астамы жұмыс істейді. Ол жұмыспен қамтуды ғана емес, азық-түлік қауіпсіздігін де қамтамасыз етеді. Мал, астық, көкөніс санының өсуі байқалады. Өңірлік деңгейде ауыл шаруашылығы өнімдерінің жоғары өсуі бойынша Ақмола (шамамен 112\%), Павлодар (шамамен $104 \%$ ) және Қостанай (шамамен 103\%) облыстарын атап өтуге болады.

Зерттеу материалдары мен әдістері. Соңғы екі жылдағы жалпы макроэкономикалық жағдай коронавирустық пандемияны ескере отырып, Қазақстандағы азық-түлік қауіпсіздігінің жағдайын негіздейді деп есептелді. Библиометриялық әдісті қолдана отырып, бастапқы көздерді талдау инвестициялардың агроөнеркәсіптік кешенді дамытуды ынталандыруда негізгі рөл атқаратынын көрсетті. Агроөнеркәсіптік кешенді дамытудың 2021-2025 жылдарға арналған ұлттық жобасы аясында инвестициялық жобаларды іске асыру үшін қомақты мемлекеттік ресурстар бөлінді.

Инвестиция көлемі жағдайында мәліметтерді топтастыру мен жалпылау әдісін қолдануды ескере отырып, ауыл шаруашылығында қолданылатын капитал деңгейінің арақатынасын динамикада сипаттау мен бөлектеу мүмкіндігі пайдаланылды.
Бұл зерттеу мақсатының шешімі талдау мен синтез әдістерін қолдануға негізделген. Мұнда инвестициялық жоспарлаудың экономикалық аспектілері аймақтық талдау мысалында ашылды.

Бақылау мен салыстырмалы талдау әдістерін ескере отырып, агроөнеркәсіптік сектордағы ауыл шаруашылығы техникасының жағдайына бағалау жүргізілді.

Алынған практикалық деректерді аймақтық контексте біріктіру шектеулі инвестициялық ресурстарды бөлу саласында жалпы мәселелерді шығаруға және ұсыныстар беруге негіз болды.

Нәтижелер және оларды талқылау. Әдеби шолу. Шетелдік және қазақстандық библиографияны зерттеу барысында инвестициялар жаңа техниканы алу үшін, сондай-ақ бәсекеге қабілетті ауыл шаруашылығы өнімдерін өндіру үшін ауыл шаруашылығы кәсіпорындары мен фермерлер үшін маңызды қаржылық ресурс болып табылатыны анықталды.

Qіапдық ғалым фермерлердің меншікті капиталына инвестициялау туралы шешім қабылдауда зерттеулер жүргізуде. Үлестік инвестициялар ауыл шаруашылығы шикізатының белгілі бір мөлшерін пропорционалды жеткізуге мүмкіндік береді. Инвестицияларды жоспарлау белгісіздік жағдайында, атап айтқанда, коронавирустық пандемия кезінде өте маңызды екені атап өтілді. Бұл, нәтижесінде, рентабельділікке және ауыл шаруашылығы өндірісін тиімді жоспарлауға оң әсер етеді [3].

Zandi және басқалардың мақаласы ғалымдар (2020 ж.) сумен жабдықтау, зиянкестер мен климаттық факторларға байланысты агросферадағы кедергілерді дәлелдейді. Бұл кедергілер агроөнеркәсіптік жобаларды жүзеге асыруда елеулі тәуекел болып көрінеді [4].

Инвестициялық ауыл шаруашылығы жобаларының табысы көп жағдайда оңтайлы шығындар мен пайдаларға байланысты. Бірақ бұл жерде маңызды кедергі - бұл белгісіздік жағдайлары және білікті ғылыми зерттеулер жүргізу үшін экономикалық мәліметтердің болмауы [5].

Тағы бір зерттеуде аймақтағы инвестициялық жоспарлаудың тиімділігі талданады. Ол Алматы облысының мысалында ауыл шаруашылығының әлеуетті өндірістік мүмкіндіктерінің болуын дәлелдейді. Аграрлық сектордағы инвестициялық жобалау мәселелеріне көп көңіл бөлінеді. Бұл ретте шетелдік және отандық инвестициялар ағыны негізінде өңдеу өнеркәсібін дамытуға үлкен көңіл бөлінеді [6]. 
Assa, Sharifi, Lyons (2020) аграрлық азық-түлік өндірісіне инвестициялардың өсуіне негізделген тәуекелдерді басқарудың негізгі аспектілерін зерттейді. Ол ауыл шаруашылық өнімдерін сақтандыру қажеттілігін анықтау үшін экономикалық және статистикалық модельді қолданады. Жеткізу тізбегі процесіне мемлекеттік және басқа да инвестиция түрлерін тарту тәртібі қолданылады деп болжануда [7].

Инвестицияларды мемлекеттік қолдаудың мақсаты - экономикалық даму үшін қолайлы инвестициялық ахуал құру. Москвин В.А. мемлекеттік қолдау негізінде инвестицияларды ынталандыру қажеттілігін атап көрсетеді. Инвестициялардың келуі жаңа өңдеу кәсіпорындары мен агроөнеркәсіптік кешендердің құрылысына әсер етеді. Бұл жерде цифрлық инновацияны қолдануға болады. Кәсіпкерлік қызметті ұйымдастыруда инвестициялық преференциялар маңызды рөл атқарады [8].

Нақты объектіге тікелей инвестициялаудың экономикалық орындылығы мен мерзімін негіздеу үшін жобалық сметалық құжаттар қажет. Атап айтқанда, Braun инвестициялық процестің ерекшелігі болашақта алынатын шығындардың бір бөлігінің белгісіздігі екенін атап көрсетеді [9].

Инвестиция мен инновация - бұл капитал салымының оңтайлы процестерін сипаттайтын тығыз байланысты категориялар. Көбінесе инновациялар жаңа техниканы өндіруде және сатып алуда жүзеге асады. Инновация кәсіпорындардың бәсекеге қабілеттілігіне айтарлықтай әсер етуі мүмкін. Сонымен қатар, инновацияның экономикалық пайдасы қарапайым инвестицияның әсерінен едәуір басым [10].

Ауыл шаруашылығындағы белгілі жетістіктерге қарамастан, Қазақстан әлі де азық-түлік тауарларына импортқа тәуелділікті сезінуде. Біріншіден, бұл ет және сүт өнімдері, құс пен балық, шұжық, қант, өсімдік майы, алма және т.б.

Сондай-ақ республикада белгілі бір жылдардағы кірістілік деңгейінде елеулі ауытқулар байқалады. Бұған қолайсыз ауа райы жағдайлары, минералды тыңайтқыштардың жетіспеушілігі, несие, жердің өнімділігі мен ауыл шаруашылық шикізатын жинауға және өңдеуге арналған технологиялық қондырғылар кіруі мүмкін.

Елдегі инфляциялық фонның артуы үлкен алаңдаушылық туғызады. Оларға электрэнергиясына, газға, жанармайға бағаның өсуі жатады (мұнда өсім 2021 жылы 13 пайыздан асады). Бұл жағдайды, біздің ойымызша, Үкіметтің фрискалды ынталандыру шараларымен түсіндіруге болады. Алайда, мұндай фрискалдық шаралар COVID пандемиясы кезінде бизнесті қолдау мен жиынтық сұранысты қолдау үшін қажет болды.

Бірақ азық-түлік бағасы - инфрляцияның екінші көзі. Атап айтқанда, олардың инфрляция құрылымындағы үлесі 11 пайыздан асады. Азық-түлік емес тауарлар, киім мен қызмет бағасы 5-7 пайызға көтерілді.

Сонымен қатар, пандемияға байланысты экспорттық нарықтар толық қалпына келтірілмеді. Әуе тасымалы екі есе өсті. Сәйкесінше, бұл азық-түлік бағасының өсуіне әкеледі.

Осылайша, соңғы 10 жылдан астам уақыт ішінде азық-түлік бағасының ең жылдам өскенін атап өтуге болады. Ал мұның басты себебі - коронавирус пандемиясы.

Біздің Үкіметтің таяу болашағына қойылатын мақсаттардың бірі - азық-түлік қауіпсіздігі резервтерін құру және агроөнеркәсіптік кешеннің бәсекеге қабілеттілігін арттыру. Мұндағы негізгі фракторлар - жобаларды мемлекеттік қолдаудың және агроөнеркәсіптік кешенге инвестиция тартудың орасан зор рөлі. Бүкіл әлемдегі ауыл шаруашылығы - бұл субсидияланатын сала, оны халықаралық тәжірибе растайды.

Елдің Ұлттық даму жоспарына сәйкес 2025 жылға қарай тікелей шетелдік инвестициялар көлемін 30 миллиард долларға жеткізу жоспарлануда [11].

Бұл 2025 жылға қарай негізгі капиталға инвестиция көлемін 30 пайызға дейін қамтамасыз етеді, бұл әлемнің қарқынды дамып келе жатқан экономикасымен (Қытай, Оңтүстік Корея және т.б.) салыстыруға болады.

Республикада 2021 жылы 2021-2025 жылдарға арналған агроөнеркәсіптік кешенді дамытудың Ұлттық жобасы қабылданды [12].

Бұл жобаны іске асыру кезінде шамамен 5 трлн. теңге түрлі инвестициялық жобаларды іске асыруға бөлінді. Мұнда ауыл шаруашылығы шикізатын өндіру мен қайта өңдеу, агроөнеркәсіптік кешеннің негізгі құралдарын техникалық жаңарту бойынша объектілер қаржыландырылады, агротехниканың озық технологиялары цифрландырылады және енгізіледі.

Инвестиция тарту елдің экономикалық әлеуетін арттыруда және бүкіл халықтың әл-ауқатын жақсартуда маңызды рөл атқарады. Алайда, пандемиялық дағдарыс кезінде қиын қалпына келтіру жеке кәсіпкерлік пен шетелдік инвестициялардың инвестициялық белсенділігінің шамалы төмендеуіне әкелді. 
Осыған байланысты мемлекеттік инвестициялар маңызды рөл атқарды. Мәселен, 2020 жылы инвестициялардың айтарлықтай өсуі құрылысқа - 2,3 есе, өңдеу өнеркәсібіне - 2,2 есе, ауыл шаруашылығына 1,7 есе артты.
2012 жылдан 2020 жылға дейінгі «Экономиканың негізгі капиталына инвестициялардың» жалпы құнындағы «Ауыл шаруашылығына инвестициялардың» үлесін талдайық (1 сурет).

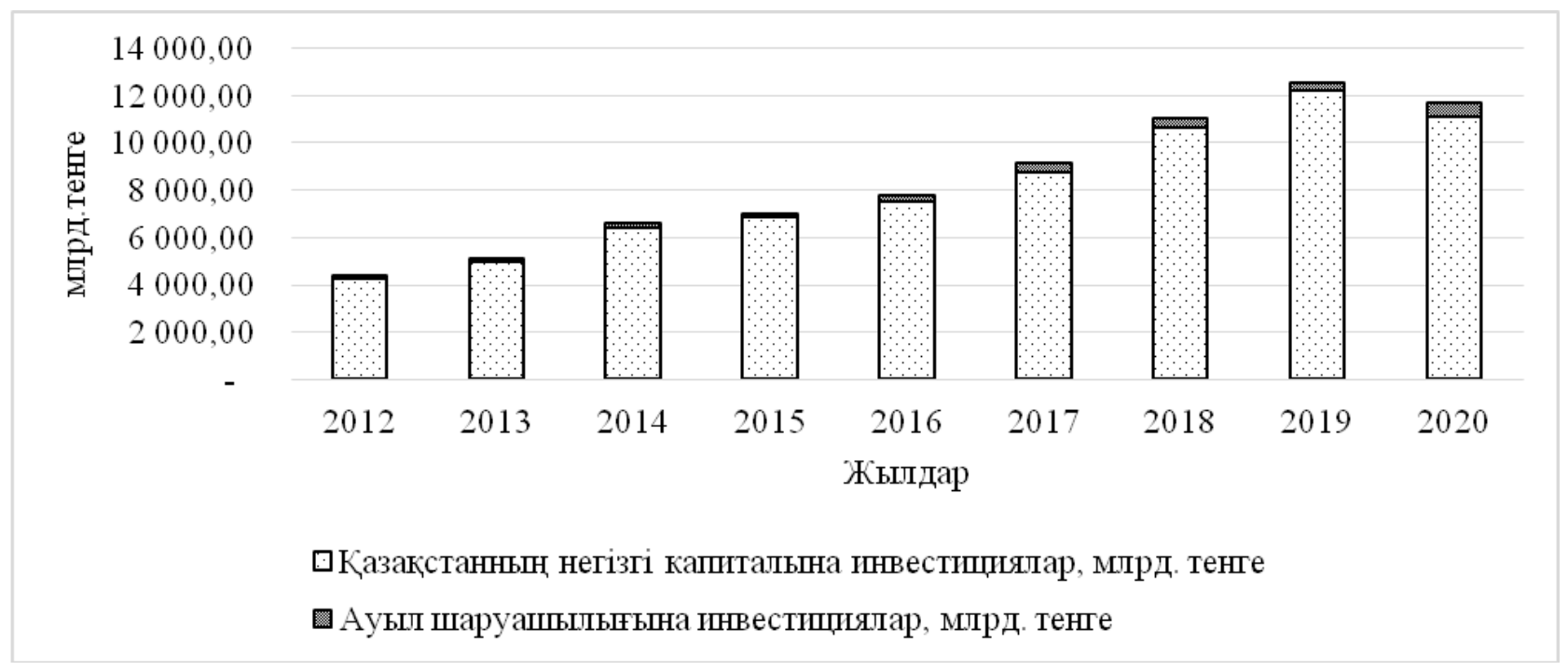

Дереккөзі: әдебиет негізінде құралған [13]

1 сурет - «Экономиканың негізгі капиталына инвестициялар»

құрылымындағы ауыл шаруашылығына инвестициялар, 2012-2020

1 суретте республиканың ұлттық экономикасына салынған инвестициялардың жалпы құрылымындағы ауыл шаруашылығына салынған инвестициялардың үлесі 3тен 5 пайызға дейін өзгергені көрсетілген. Соңғы 10 жылда ауыл шаруашылығындағы негізгі капиталға инвестициялардың ең үлкен өсуі 2020 жылға келеді: ол 5 пайыздан сәл асады.

Капиталдың 2020 жылғы ең үлкен тартымдылығы пандемиялық корона дағдарысына қарсы күрес және халықты азықтүлік өнімдерімен қамтамасыз ету аясында мемлекеттік қолдау шараларымен түсіндіруге болады.

Бұл жерде 2020 жылы Қазақстанның ІЖӨ-де ауыл шаруашылығының үлесі 5,6 пайызды құрағанын атап өткен жөн.

Естеріңізге сала кетейік, 2020 жылы ауыл шаруашылығына негізгі капиталға инвестиция ағыны 573,2 млрд. теңгені, ал азық-түлік өндірісіне - 104 млрд. теңгені құрады. Демек, агроөнеркәсіп кешеніне жалпы инвестиция көлемі 677,2 млрд. теңгені құрады, бұл жоспарға қарағанда 154,2 млрд. теңгеге жоғары. Мұнда ең жоғары өсімді екі аймақ көрсетті: оңтүстікте - Шымкент қаласы және солтүстікте Ақмола облысы.
2021 жылы (8 айда) негізгі капиталға салынған инвестициялар құрылысқа (150 пайыздан астам), өңдеу өнеркәсібіне (80 пайыздан астам), ауыл шаруашылығына (43 пайыздан астам немесе 430 млрд.теңгеден астам) өсті. Бұл жерде Үкіметтің фискалдық реттеу шаралары аса маңызды болды.

Агроөнеркәсіптік кешенге инвестицияларды мемлекеттік қолдау құрылымын қарастырыңыз (2 сурет).

Мұнда «инвестициялық жоба» қолданыстағы өндірістік қуаттарды жаңартуға инвестиция тартылады деп болжайды. Мемлекет мұндай жобаларды шикізат импортына ҚҚС төлеуден және жабдық пен қосалқы бөлшектерге баж салығын 5 жылға дейін босатады. Сонымен қатар, инвестицияның 30 пайызына дейін грант бөлінеді.

Инвестициялық басымдылық жобасының нысаны жаңа құрылысқа немесе ескі нысанды жаңғыртуға негізделген. Инвестиция көлемі 2 млн АЕК баламасынан жоғары болуы керек (немесе 5 млрд. теңге деңгейінде). Бұл жағдайда жобаның бұл түрі 5 жылға дейінгі мерзімге шикізат импорты, мүлік және жер салығы, КТС, техникалық жабдықтар мен шикізатқа кедендік баж салығынан босатылады. Субсидия деңгейінде жабдық құнының 30\% дейін беріледі. 


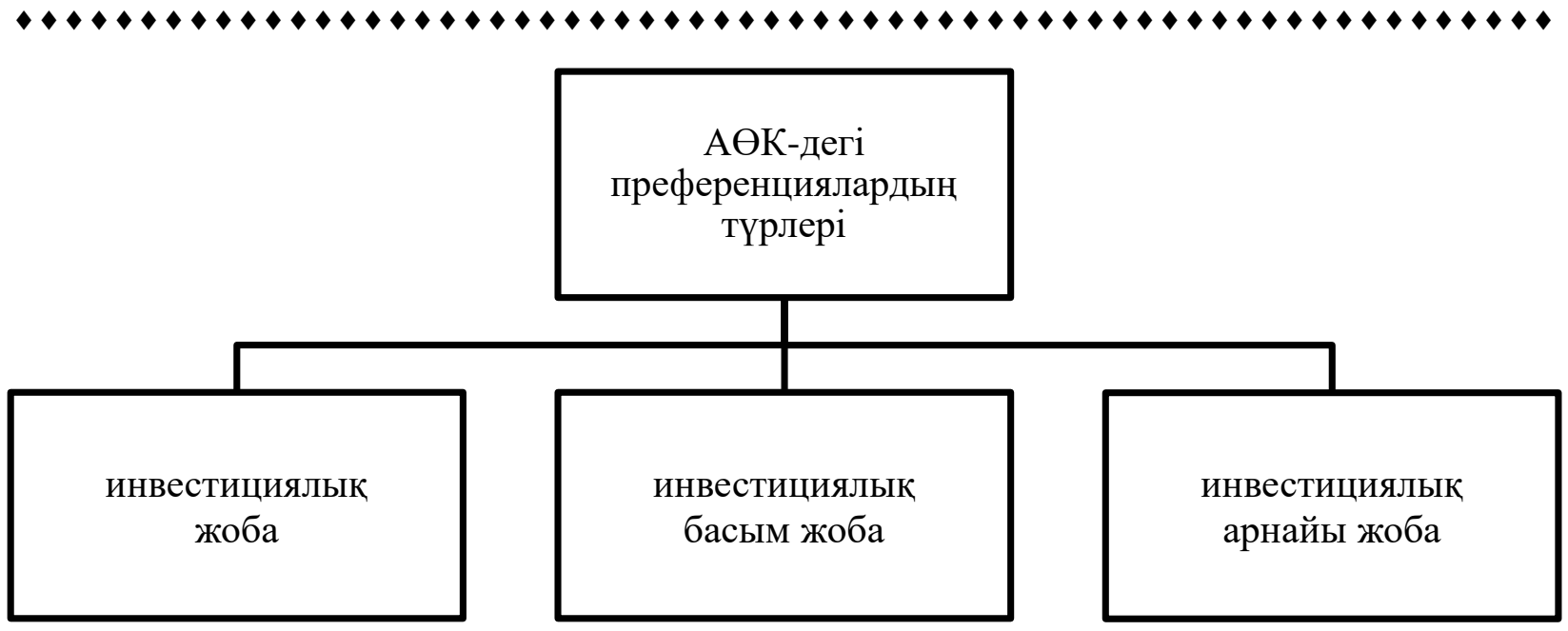

Дереккөзі: әдебиет негізінде құралған [14]

2 сурет - Агроөнеркәсіптік кешенге инвестицияларды мемлекеттік қолдау

Ал соңғысы «Инвестициялық арнайы жоба» 15 жылға дейінгі мерзімге жабдықтар мен бөлшектерге кедендік баж салығынан босатуды қарастырады. Инвесторлар ҚҚС, КТС, жер және мүлік салығынан босатылады.

Сонымен қатар, ҚР Ауыл шаруашылығы министрлігі ауыл шаруашылығы кәсіпкерлерінің дамуын қолдау үшін «Банктік кредиттерге кепілдік беру механизмін» әзірледі. Кепілдік алуға қойылатын талаптар келесідей: несие сомасы 10 жылдан аспайтын мерзімге 5 млрд. Теңгеден аспайды. Бұл ретте сыйақы мөлшерлемесі 17 пайыздан аспайды. «Ауыл шаруашылығын қаржылай қолдау қоры» АҚ несие сомасының 50 пайызына дейін кепілдік береді. Маңызды ескерту - мұндай несиеге қатысушылар кепілдік мүлкі жоқ кәсіпкерлік субъектілері болып табылады.

Агроөнеркәсіптік кешен саласындағы жалпы индустрияландыру жылдарында жалпы құны 9,1 трлн. 1 500-ден астам жоба жүзеге асырылғанын атап өтейік. Теңге және 200 мыңнан астам жаңа жұмыс орындары ашылды. Сонымен бірге жобалардың 90\%-ға жуығы жеке қаражат есебінен қаржыландырылды.

2020 жылы жалпы сомасы 202 млрд. теңгеден асатын 186 инвестициялық жоба қаржыландырылды. Құрылымы бойынша мал шаруашылығында 113 жоба (133 млрд. теңгеден астам), өсімдік шаруашылығында 73 жоба (70 млрд. теңге) жүзеге асырылды.

Жалпы 2021 жылға дейін агроөнеркәсіп кешенінде 280-нен астам инвестициялық жобаны іске асыру жоспарлануда. Бұл ретте ауылдық жерлерде 7 мыңнан астам жаңа жұмыс орындары ұйымдастырылады. Атап айтқанда, 134 жоба тек
Аграрлық несие корпорациясының (АӨК) бағдарламаларын қаржыландыру негізінде жүзеге асырылды. Несие көлемі 2021 жылдың бірінші жарты жылдығына 5,9 млрд.

Мысалы, осы қаражат есебінен 6 сүт фермасы, 2 құс фрабрикасы, 1,5 мың тоннаға 1 жеміс сақтау қоймасы салынды.

Барлығы 2021-2025 жылдарға қабылданған Жол карталары аясында 900-ден астам жобаны іске асыруға шамамен 4,5 трлн. теңге бөлінеді. Нәтижесінде бұл 500 мыңнан астам жаңа жұмыс орындарының ашылуына, 70 мыңнан астам отбасылық шаруа қожалықтарының ұйымдастырылуына және еңбек өнімділігінің 2,5 есеге және 1 миллионға жуық ауыл тұрғындарының табысының артуына әкеледі деп болжануда.

Атап айтқанда, 2022 жылы суландыру жүйелерін шығаратын зауыт құрылысы жобасы жүзеге асырылады (өндірістік қуаты жылына 1000 бірлікке дейін). Бұл 3 млн тоннаға дейін ауыл шаруашылығы өнімдерін өндіру мүмкіндігіне және 20 пайызға дейін су үнемдеу технологияларын қолдану алаңдарын жабуға әкеледі. Біз республиканың кейбір аймақтарына аграрлық секторға инвестиция тартуды бағалаймыз.

Сонымен, Солтүстік Қазақстан облысында 2021-2025 жылдары 100 млрд. теңгеге дейін инвестициялық ауыл шаруашылығы объектілері пайда болады. 1 000нан астам адам жұмыспен қамтылады. Мұндағы ең ірі жоба - шошқа өсіру кешенін 2023 жылдан бастап 500 мың басқа дейін жаңғырту. 2025 жылға дейін Өндірістік қуаттылығы жылына 50 мың тоннаға дейін ет болады, жобаның жалпы құны шамамен 55 млрд. теңге. 
Қарағанды облысында 2021 жылдан бастап сүт өнеркәсібінде 22 млрд. теңгеден астам сомаға 15 жобаны іске асыру басталды. Мысалы, 2022 жылы жалпы құны 1,35 млрд. теңгені құрайтын сүт фермасының құрылысы аяқталады. Мұнда жылына 3 мың тонна өнім шығару жоспарлануда. Жалпы, тек 4 ірі жоба бойынша 2021-2025 жылдарға 302,8 млрд. теңге тарту жоспарланып отыр.

Батыс Қазақстан облысында 2021-2025 жылдарға жалпы құны 165 млрд. теңгеден асатын 94 ауыл шаруашылығы жобасын іске асыру жоспарлануда. Атап айтқанда, 2021 жылы жылына 7 мың тоннадан астам көкөніс өсірілетін жылыжай іске қосылады. Жоба құны - 14 млрд. теңге. Сондай-ақ 2022 жылы 2,5 млрд. теңгеге мал бордақылау алаңын салу жоспарлануда.

2021-2025 жылдар аралығында 6 ірі агроөнеркәсіптік жоба жүзеге асырылады, Қостанай облысында 17 млрд. теңге көлеміне жоспарланып отыр. Мысалы, қазірдің өзінде 2021 жылы құны 6 млрд. теңгеге жуық ет комбинаты іске қосылады. Онда
184 адам жұмыс істейтін болады. Бұл зауыттың өндірістік қуаты жылына 20 мың тоннаны құрайды. Сонымен қатар, өзінің шикізатын өңдеуге арналған шошқа өсіру кешені жаңғыртылады. Жобаның өндірістік қуаты жылына 1,7 мың тонна деңгейінде 600 млн теңге көлемінде инвестиция тартумен жоспарланған.

2021 жылы Жамбыл облысында ауыл шаруашылығының бес жобасы іске қосылды. Мұнда жылына жұмыртқа мен 8 мың тонна құс етін өндіретін екі құс фабрикасы ашылады. Жобаның жалпы құны 8,2 млрд. теңгені құрайды. Сондай-ақ, 263 млн. теңге деңгейінде капитал тартумен жылына 720 тонна жоспарлы қуаттылығы бар 200 бас фрермасы іске қосылады. 2022 жылы құны 242 млн. доллар болатын қант өңдеу зауытының құрылысы басталады.

Ауыл шаруашылық кәсіпорындары мен шаруа қожалықтарындағы ауыл шаруашылығы техникаларының жағдайына жасалған талдау оларды қаржыландыру әлі де жеткіліксіз екенін көрсетті (3 сурет).

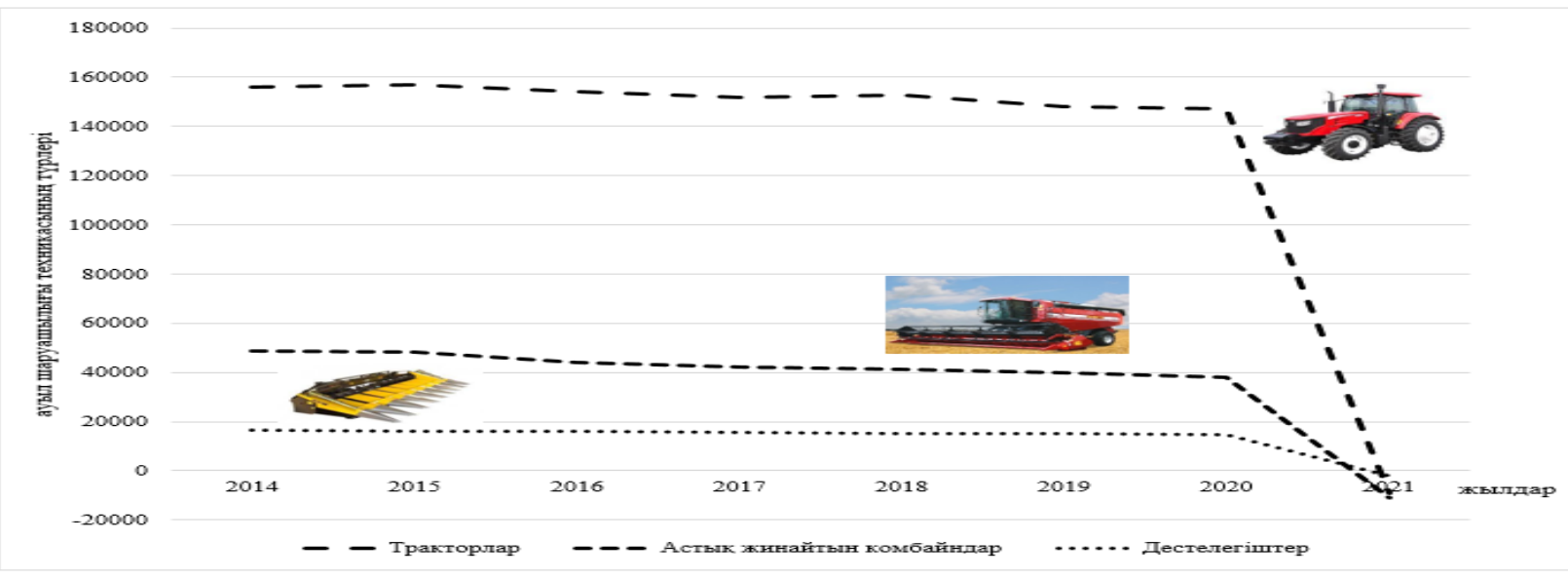

Дереккөзі: әдебиет негізінде құралған [15]

3 сурет - Ауыл шаруашылығы техникасының негізгі түрлері, агрегаттары

Кестедегі мәліметтерден жаңа жабдықтардың саны жыл сайын азайып бара жатқанын көруге болады. Бұдан басқа, ауыл шаруашылығы техникасының тозуы бар. Жыл сайын ауыл шаруашылық техникасын сатып алуға қаржы бөлінеді, бірақ әлі де қаржылық ресурстардың тапшылығы байқалады.

Мысалы, 2020 жылы аграрлық компаниялар мен фермерлер 15 мыңнан астам техника сатып алды. Бұл 2019 жылғы қаражаттан 30\%-ға, ал 2021 жылдың 1 жарты жылдығына «ҚазАгроҚаржы» ұйымының ресурстарына сәйкес, ауыл шаруашылығы тауар өндірушілері шамамен 100 млрд. теңгеге 5 500-ден астам техника сатып алды. Бұл 2020 жылмен салыстырсақ са-тып алу көлемінен бірнеше есе көп.

Жалпы, қарастырылып отырған кезеңде компаниялар 150 млрд. теңгеге 10 мыңнан астам ауыл шаруашылығы техникасын сатып алды. 2021 жылдың соңына дейін жалпы сомасы 240 млрд. теңгеге дейін ауыл шаруашылығы техникасын сатып алу жоспарлануда.

Сонымен қатар инновациялық егіншілік жүйесімен жабдықтар сатып алынуда. Әлемге әйгілі «Джон Дир» компаниясы фермерлерге ауыл шаруашылық техни- 
касы мен техникалық кеңестер алуға үлкен қолдау көрсетеді.

Агроөнеркәсіптік секторда инвестициялардың белгілі бір көлемі ақпараттық технологиялар мен инновацияларға бағытталғанын бөліп көрсетейік. Жалпы, 2021 жылы ұлттық экономиканы дамытуға 254 млрд. теңге инвестиция жұмсалады. Ал 2020 жылы ІТ-технологияларға салынған инвестициялар 193 млрд. теңге. Келесі 2022 жылы мұндағы инвестиция ағыны 335 млрд. теңгеге дейін өседі, ал болашақта 2023 жылы - 448 млрд. теңгеге дейін өседі деп жоспарлануда.

Бұл ретте ЖІӨ құрылымындағы инновациялық өнім өндірісі, оның ішінде аграрлық сектордың үлесі 3 пайызға жетеді. Жетілдірілген шет елдермен салыстырғанда, бұл инновациялық ауыл шаруашылығы өнімдерін өндірудің жеткіліксіз деңгейі сияқты.

Бағалау көрсеткендей, мал шаруашылығы саласындағы инвестициялық жобаларды іске асыру тәжірибесі тек өндірістік процесті ғана қамтымауы тиіс. Мұнда сонымен қатар республика аймақтарында берік жемшөп базасын құру үшін жобалық қаржыландыруды бөлу қажет. Бұл мал шаруашылығының қажеттіліктері үшін жоғары сапалы жем алу үшін, жаңа жем зауыттарын салу және жануарларды толыққанды азықтандыруды ұйымдастыру үшін қажет.

Бұл әсіресе Қазақстанның кейбір аймақтарындағы жаһандық жылыну мен құрғақшылық аясында айқын көрінді. Coнымен, 2021 жылдың жазында ұзақ уақытқа созылған құрғақшылықтың нәтижесінде ауыл шаруашылығы алқаптары зардап шекті. Құрғақ жел егінге зиян келтіріп, азықтүлік қорын азайтты.

Асылдандыру жұмыстарының тиімділігі тұрақты түрде қаржыландыруға және жергілікті ауыл шаруашылығы жануарларының генетикалық жетістіктері мен асылдандыру сапасына байланысты. Өз кезегінде, асыл тұқымды жұмыстар кешеніне азықтандырудың ғылыми негізделген нормалары мен табиғи ресурстарды ұтымды пайдалану қажет. Бұл бағытқа инвестиция салмайынша, мал шаруашылығы біртіндеп дамымайды.

Сонымен қатар мұнда ауыл шаруашылығындағы нақты әртараптандырудың дамуын атап өткен жөн. Бұл климаттық апаттардың өсімдік шаруашылығына теріс әсерін төмендетуге, сондай-ақ мал шаруашылығының жемшөп базасын дамытуға мүмкіндік береді.

Инвестициялық жобалар арқылы ауыл шаруашылық техникасы мен технологиясын жеткіліксіз сатып алу күрделі мә- селелер туғызады. Ауыл шаруашылығы тауар өндірушілерін қолдаудың белгілі мемлекеттік тетіктеріне қарамастан, техниканың тозуы жоғары және жаңа агротехнологияларды енгізудің жоқтығы байқалады. Осыған байланысты, жаңа жобаларды әзірлеу кезінде инновациялық ауыл шаруашылығы техникасы мен аграрлық сектордың технологиялық базасының байыпты инновациялық жабдықтарын алу саласындағы шаруа қожалықтары мен компанияларды несиелендіру мен қаржыландыруға ерекше назар аудару қажет.

Осылайша, мемлекеттік және отандық жеке және шетелдік инвестициялар есебінен инвестиция тартуды күшейту ауыл шаруашылығы тауар өндірушілерінің әлеуетін арттырады. Бұған қоса, бұл инвестициялық инъекцияларды енгізудің жылдамдығы мен табыстылығын, оның ішінде ауыл шаруашылығы өнімдерін өндіру мен қайта өңдеу инфрақұрылымын дамытуға мүмкіндік береді.

\section{Қорытынды.}

1. Агроөнеркәсіптік кешенге инвестиция тартуда келесі мәселелерді ажыратуға болады. Агроөнеркәсіптік кешенге инвестиция салуды тежейтін маңызды факторлар: COVID-19 жаңа толқыны, азық-түлік инфляциясының жоғарылау қаупі, бизнесті қаржыландырудың нашарлауы және инвестиция ағынының болмауы.

2. Цифрландыруды енгізудің, жаңа инновациялық агротехнология мен техниканы алудың экономикалық тиімділігін түсінбеу.

3. Осы мәселелерді шешудің мүмкін болатын мақсаттары үшін осындай ұсыныстар ұсынылады. Үкіметке инвестиция тарту, тиімді бизнес ортаны ұйымдастыру, іскерлік ахуалды жақсарту, белгілі бір салық режимін, орташа лизинг пен АӨК субъектілеріне жеңілдіктер беру бойынша жүйелі шараларды жалғастыру қажет.

4. Ауыл шаруашылығы өндірісін қаржыландырудың қолжетімділігін қамтамасыз ету процесін үнемі жетілдіру және оңтайландыру қажет. Азық-түлік қауіпсіздігі мәселесін шешуге назар аудару қажет. Бұл әсіресе коронавирустық пандемия кезінде дұрыс.

5. Ресурс үнемдеу және цифрлық технологияларды қолдана отырып, агроөнеркәсіптік кешеннің материалдық-техникалық базасын жаңартуды жалғастыру, сондай-ақ жаңа ауыл шаруашылығы кешендерін басқаруда ақылды жүйелерді сатып алу және енгізу қажет. Жаңа инвестициялық жобаларды әзірлеу мен енгізу еңбек өнімділігін және қазақстандық азық-түлік тауарларының бәсекеге қабілеттілігін арттырады. 


\section{Әдебиетmер тізімі}

[1] Смагулова, Ш.А. Қазақстанның мемлекеттік даму бағдарламаларын жүзеге асыруда жобалық басқаруды енгізу / Ш.А. Смагулова // Central Asian Economic Review. - 2020. - №6 (135). - Б. 6-19.

[2] Данные Министерства национальной экономики РК [Электронный ресурс].-2021.URL: https://www.gov.kz/memleket/entities/economy/press/news/details/268033?lang=ru/ (дата обращения: 12.10.2021).

[3] Qian, X. Production planning and equity investment decisions in agriculture with closed membership cooperatives / X. Qian // European Journal of Operational Research. - 2021.- Vol. 294. - n. 2. - P.684-699.

[4] Zandi, P. Agricultural Risk Management Using Fuzzy TOPSIS Analytical Hierarchy Process (AHP) and Failure Mode and Effects Analysis (FMEA) / P. Zandi, M. Rahmani, M.Khanian \& A.Mosavi // Agriculture. - 2020. - Vol. 10. - n. 11. - P.1-28.

[5] Yet, B. Evidence-based investment selection: Prioritizing agricultural development investments under climatic and socio-political risk using Bayesian networks / B. Yet, C. Lamanna, K.D. Shepherd \& T.S. Rosenstock // PLOS ONE. - 2020. - Vol. 15. - n. 6. - P.1-22.

[6] Смагулова, Ш.А. Қазақстанның Алматы облысында инвестициялық жобаларды жүзеге асыру / Ш.А. Смагулова // Проблемы агрорынка. - 2020. - №4. - Б.86-93.

[7] Assa, H. An examination of the role of price insurance products in stimulating investment in agriculture supply chains for sustained productivity / H. Assa, H. Sharifi \& A. Lyons // European Journal of Operational Research. 2020. - Vol. 288. - n. 3. - P. 918-934.

[8] Москвин, В.А. Инвестиционные проекты в мире социальных систем: монография / В.А. Москвин. - М.: Инфра-М, 2016. - 254c.

[9] Braun, T. Configurations for Interorganizational Project Networks: The Interplay of the PMO and Network Administrative Organization / T. Braun // Project Management Journal. - 2018. - Vol. 49. - n. 4. - P. 53-61.

[10] Steen, J. A Dynamic Capabilities Model of Innovation in Large Interfirm Projects / J. Steen, J.A. Ford \& M.-L. Verreynne // Project Management Journal.- 2021.- vol.52.-P.488-503.

[11] Национальный план развития страны до 2025 года [Электронный ресурс].-2021.URL: https://www.gov.kz/memleket/entities/economy/press/news/details/174689?lang=ru/ (дата обращения: 17.03.2021).

[12] Национальный проект по развитию агропромышленного комплекса РК на 20212025 годы. Министерство сельского хозяйства РК [Электронный ресурс].- 2020.URL:https://www.gov.kz/memleket/entities/karag anda-agro/press/news/details/247099?lang=kk/ (дата обращения: 26.08.2021)

[13] Данные Бюро национальной статистики Агентства по стратегическому планированию и реформам Республики Казахстан [Электронный ресурс]. -2021 .- URL: https://stat.gov.kz/for_users/dynamic/ (дата обращения: 10.10.2021).

[14] Данные Министерства сельского хозяйства РК [Электронный ресурс]. - 2021.URL: https://www.gov.kz/memleket/entities/moa/ press/news/details/17352?lang=ru/ (дата обращения: 09.10.2021).

[15] Автопарк сельхозтехники критически устарел в Казахстане [Электронный ресурс]. 2020. - URL: https://pkzsk.info/avtopark-selkhoztekhniki-kriticheski-ustarel-v-kazakhstane (дата обращения: 02.04.2020).

\section{References}

[1] Smagulova, Sh.A. (2020). Qazaqstannyñ memlekettık damu bağdarlamalaryn jüzege asyruda jobalyq basqarudy engızu [Introduction of project management in the implementation of state development programs of Kazakhstan]. Central Asian Economic Review, 6 (135), 6-19 [in Kazakh].

[2] Dannye Ministerstva nacional'noj ekonomiki RK [Data of the Ministry of National Economy of the Republic of Kazakhstan]. (2021). Available at: https://www.gov.kz/memleket/entities/economy/press/news/details/268033 ?lang=ru/ (date of access: 12.10.2021) [in Russian].

[3] Qian, X. (2021). Production planning and equity investment decisions in agriculture with closed membership cooperatives. European Journal of Operational Research, 294(2), 684699 [in English].

[4] Zandi, P., Rahmani, M., Khanian, M., \& Mosavi, A. (2020). Agricultural Risk Management Using Fuzzy TOPSIS Analytical Hierarchy Process (AHP) and Failure Mode and Effects Analysis (FMEA). Agriculture, 10(11), 1-28 [in English].

[5] Yet, B., Lamanna, C., Shepherd, K.D., \& Rosenstock, T.S. (2020). Evidence-based investment selection: Prioritizing agricultural development investments under climatic and sociopolitical risk using Bayesian networks. PLOS ONE, 15(6), 1-22 [in English].

[6] Smagulova, Sh.A. (2020). Qazaqstannyñ Almaty oblysynda investisialyq jobalardy jüzege asyru [Implementation of investment projects in Almaty region of Kazakhstan]. Problemy agrorynka - Problems of agrimarket, 4, 86-93. [in Kazakh].

[7] Assa, H., Sharifi, H., \& Lyons, A. (2020). An examination of the role of price insurance products in stimulating investment in agriculture supply chains for sustained produc- 
tivity. European Journal of Operational Research, 288 (3), 918-934 [in English].

[8] Moskvin, V.A. (2016). Investicionnye proekty $\mathrm{v}$ mire social'nyh sistem: monografiya [Investment projects in the world of social systems]. - M.: Infra-M, 254p. [in Russian].

[9] Braun, T. (2018). Configurations for Interorganizational Project Networks: The Interplay of the PMO and Network Administrative Organization. Project Management Journal, 49(4), 53-61 [in English].

[10] Steen, J., Ford, J. A., \& Verreynne, M.L. (2021). A Dynamic Capabilities Model of Innovation in Large Interfirm Projects. Project Management Journal, 52, 488-503 [in English].

[11] Nacional'nyj plan razvitiya strany do 2025 goda [National development plan of the country until 2025]. (2021). Available at: https://www.gov.kz/memleket/entities/economy/p ress/news/details/174689?lang=ru/ (date of access: 17.03.2021) [in Russian].

[12] Nacional'nyj proekt po razvitiju agropromyshlennogo kompleksa RK na 2021-2025 gody. Ministerstvo sel'skogo hozjajstva RK [Na- tional project for the development of the agroindustrial complex of the Republic of Kazakhstan for 2021-2025. Ministry of Agriculture of the Republic of Kazakhstan]. (2020). Available at: https://www.gov.kz/memleket/entities/karaganda -agro/press/news/details/247099?lang=kk/ (date of access: 26.08.2021) [in Kazakh].

[13] Dannye Nacional'nogo byuro statistiki [Data from the National Bureau of Statistics]. (2021). Available at: https://stat.gov.kz/ for users/dynamic/ (date of access: 10.10.2021) [in Kazakh].

[14] Dannye Ministerstva sel'skogo hozyajstva RK [Data of the Ministry of Agriculture of the Republic of Kazakhstan]. (2021). Available at: https://www.gov.kz/memleket/entities/ moa/press/news/details/17352?lang=ru/ (date of access: 09.10.2021) [in Russian].

[15] Avtopark sel'hoztekhniki kriticheski ustarel $v$ Kazahstane [The fleet of agricultural machinery is critically outdated in Kazakhstan]. (2020). Available at: https://pkzsk.info/avtoparkselkhoztekhniki-kriticheski-ustarel- v- kazakhstane (date of access: 02.04.2020) [in Russian].

\section{Автор туралы ақпарат:}

Смағұлова Шолпан Асылханқызы - негізгі автор; экономика ғылымдарының докторы, профессор; «Халықаралық қатынастар және менеджмент» ғылыми-білім беру кафедрасының профессоры; Нархоз университеті; 050035 Жандосов көш., 55, Алматы қ., Қазақстан; е-таіl: shsmagulova@mail.ru; https://orcid.org/0000-0002-8455-4531.

\section{Information about author:}

Smagulova Sholpan Asylkhanovna - The main author; Doctor of Economic Sciences, Professor; Professor of the Scientific and Educational Department "International Relations and Management"; Narxoz University; 050035 Zhandosova str., 55, Almaty, Kazakhstan; e-mail: shsmagulova@mail.ru; https://orcid.org/0000-0002-8455-4531.

\section{Информация об авторе:}

Смагулова Шолпан Асылхановна - основной автор; доктор экономических наук, профессор; профрессор научно-образовательного департамента «Международные отношения и управление»; Университет Нархоз; 050035 ул. Жандосова, 55, г.Алматы, Казахстан; e-mail:shsmagulova@mail.ru; https://orcid.org/0000-0002-8455-4531. 